J. Dairy Sci. 96:7777-7789

http://dx.doi.org/10.3168/jds.2013-6782

(c) American Dairy Science Association ${ }^{\circledR}, 2013$.

\title{
Selection of tropical lactic acid bacteria for enhancing the quality of maize silage
}

\author{
A. O. Santos, ${ }^{*}$ C. L. S. Ávila, $\dagger^{1}$ and R. F. Schwan* \\ *Department of Biology, and \\ †Department of Animal Science, Federal University of Lavras, 37,200-000, Lavras, Minas Gerais, Brazil
}

\begin{abstract}
The objective of this study was to select lactic acid bacteria (LAB) strains isolated from silage and assess their effect on the quality of maize silage. The LAB strains were inoculated into aqueous extract obtained from maize to evaluate their production of metabolites and $\mathrm{pH}$ reduction. The ability to inhibit the pathogenic and silage-spoilage microorganisms' growth was evaluated. Nine LAB strains that showed the best results were assessed in polyvinyl chloride experimental silos. The inoculation of the LAB strains influenced the concentration of lactic and acetic acids and the diversity of Listeria. The inoculation of silages with Lactobacillus buchneri (UFLA SLM11 and UFLA SLM103 strains) resulted in silages with greater LAB populations and improvements after aerobic exposure. The UFLA SLM11 and SLM103 strains identified as L. buchneri showed to be promising in the treatment of maize silage. Key words: inoculant, lactic acid bacteria, silage, acetic acid
\end{abstract}

\section{INTRODUCTION}

Traditionally, the most widely used forage for ensiling is the maize plant (Zea mays L.). In addition to its nutritional quality, maize has desirable features for ensiling, such as a high production of DM per area unit, an adequate fermentation pattern in the silo due to DM content between 28 and $40 \%$, an adequate concentration of soluble carbohydrates, and low buffering capacity (Nussio et al., 2001). Maize silages, however, are susceptible to aerobic deterioration (Siqueira et al., 2005). Thus, the use of microbial inoculants in these silages has been recommended, with the primary goal of reducing aerobic deterioration and preserving the silage's nutritional value (Kung et al., 2003).

Spoilage and pathogenic microorganisms can be a problem in maize silages. Bacteria of the genera Clos-

Received March 8, 2013.

Accepted August 14, 2013.

${ }^{1}$ Corresponding author: csilvaavila@gmail.com tridium, Listeria, and Bacillus, and the family Enterobacteriaceae have been reported in maize silages (Rossi and Dellaglio, 2007; Dunière et al., 2011; Konosonoka et al., 2012). Nevertheless, studies in the selection of inoculants aimed at inhibiting the growth of these deteriorating and pathogenic microorganisms are still scarce (Saarisalo et al., 2007; Marciňáková et al., 2008). Yeasts and filamentous fungi are the main microorganisms involved in the aerobic deterioration process of silages. Studies have shown that some lactic acid bacteria (LAB) strains can exhibit antimicrobial activity, thereby affecting many pathogenic and deteriorative microorganisms (Gollop et al., 2005).

Some authors have reported the effects of microbial inoculants on the fermentation of silages; however, few descriptions of the selection process of bacteria strains are used for this purpose. The purpose of the present study was to select LAB strains with the potential to improve the fermentative characteristics and inhibit the growth of pathogenic and spoilage microorganisms and to assess the effect of the inoculation of these strains on the nutritional value and aerobic stability of maize silages.

\section{MATERIALS AND METHODS}

\section{Selection of Bacterial Strains for Inoculants}

Lactic acid bacteria strains were originally isolated in sugar cane silage (Ávila et al., 2010a) and were preselected based on the assessment of growth and production of metabolites in the aqueous extract obtained from maize plants and their ability to inhibit the growth of pathogenic and silage-spoilage microorganisms. The aqueous extract for fermentation was obtained through chopping and grinding the entire maize plant according to Saarisalo et al. (2007). Seventy-five LAB strains were cultivated in de Man, Rogosa, Sharpe broth (M369; Himedia, Mumbai, India) for $24 \mathrm{~h}$ at $30^{\circ} \mathrm{C}$. Subsequently, a standardization of the inoculum was performed using the number 1 standard of the McFarland scale. Then, $400 \mu \mathrm{L}$ of each inoculum was added to $200 \mathrm{~mL}$ of aqueous extract from the maize plant, which was incubated at $30^{\circ} \mathrm{C}$ and $120 \mathrm{rpm}$ for $48 \mathrm{~h}$. 
To evaluate inoculum growth, decreases in $\mathrm{pH}$ value, and metabolite production, samples were collected immediately after inoculation and after $3,6,12,24$, and 48 $\mathrm{h}$ of fermentation. Growth was assessed by turbidimetry in a spectrophotometer at $600 \mathrm{~nm}$ (Shimadzu model UV-2501; Shimadzu Corp., Tokyo, Japan); a digital potentiometer was used to measure the $\mathrm{pH}$, and HPLC was used to analyze metabolite production. The metabolite analysis was conducted with $24 \mathrm{~h}$ of fermentation in liquid phase chromatography (Shimadzu model LC-10Ai) equipped with refractive index detectors (for ethanol; model RID-10A) and UV detectors (for lactic, acetic and propionic acids; model SPD-10Ai). A cation exchange column (Shimadzu Shim-pack SCR-101H; $30 \mathrm{~cm}$ of length and $7.9 \mathrm{~mm}$ of diameter) was used, and the temperature of the column oven was $30^{\circ} \mathrm{C}$ for ethanol readings and $50^{\circ} \mathrm{C}$ for acid readings. Ultra-pure water, with its $\mathrm{pH}$ adjusted to 2.1 with perchloric acid, was used in the mobile phase, and the flow rate was 0.6 $\mathrm{mL} / \mathrm{min}$.

The 65 LAB strains that exhibited the best growth and efficiency in the reduction of $\mathrm{pH}$ were evaluated according to their ability to inhibit the growth of pathogenic and spoilage microorganisms. The pathogenic strains tested were Clostridium perfringens (ATCC 3624) and Listeria monocytogenes (ATCC 19117), and the deteriorative microorganisms were Escherichia coli (ATCC 11229), Bacillus cereus (ATCC 11778), and 9 yeast strains isolated from sugar cane silage (Ávila et al., 2010b).

Inhibition tests were performed using an agar-diffusion method according to the methodology described by Weese and Rousseau (2005), with some modifications. Pathogenic and deteriorative microorganisms were reactivated in brain heart infusion (Himedia) medium and incubated for $24 \mathrm{~h}$ at $37^{\circ} \mathrm{C}$, except for C. perfringens, which was incubated under anaerobic conditions in an anaerobic chamber (Thermo Scientific, model 1025; Ottawa, Canada) for $7 \mathrm{~d}$. The yeast and LAB species assessed were reactivated, respectively, on yeast extract peptone glucose (YEPG) medium $[0.3 \%$ of yeast extract (Merck, Darmstadt, Germany); $0.3 \%$ malt extract (Merck); $0.5 \%$ peptone (Himedia); $1.0 \%$ glucose (Merck); $2.0 \%$ agar (Merck) per liter, containing $100 \mathrm{mg}$ of chloramphenicol (Sigma-Aldrich, Milan, Italy)] and de Man, Rogosa Sharpe medium (M641I, Himedia) and incubated for $24 \mathrm{~h}$ at $30^{\circ} \mathrm{C}$. Standardized suspensions of the growth of the deteriorative and pathogenic microorganisms assessed were prepared and compared with the McFarland 0.5 standard (approximately $1.5 \times 10^{8} \mathrm{cfu} / \mathrm{mL}$ ), whereas LAB growth was standardized by comparing it with the McFarland 1 standard (approximately $3 \times 10^{8} \mathrm{cfu} / \mathrm{mL}$ ).
On plates containing Mueller Hinton medium (Himedia), a superficial spread was performed using a sterile swab soaked in a suspension of the pathogenic or deteriorative microorganism to be analyzed. Subsequently, using sterile tweezers, filter-paper disks of approximately $5 \mathrm{~mm}$ in diameter were placed in triplicate on the medium with the suspension, to which $50 \mu \mathrm{L}$ of the LAB suspension was added to be tested for its ability to inhibit growth of pathogenic and deteriorative microorganisms. Plates were incubated at $35^{\circ} \mathrm{C}$ for $24 \mathrm{~h}$ in aerobiosis, except for plates on which the inhibition of $C$. perfringens was assessed, which were incubated under anaerobic conditions at $35^{\circ} \mathrm{C}$. Inhibition was assessed by the formation of halos around the disks, with no growth of reference pathogenic and deteriorative microorganisms. The readings of the inhibition halos were measured in millimeters using a caliper.

\section{Molecular Identification of Selected Bacterial Strains}

The strains selected for evaluation in the polyvinyl chloride (PVC) experimental silos were identified by DNA sequencing. Bacteria cultures were grown under appropriate conditions and collected from MRS agar plates with a sterile pipette tip and resuspended in 40 $\mu \mathrm{L}$ of PCR buffer. The suspension was heated for $10 \mathrm{~min}$ at $95^{\circ} \mathrm{C}$ and $2 \mu \mathrm{L}$ was used as a DNA template in PCR experiments to amplify the full-length the $16 \mathrm{~S}$ region. An approximately 1,500 bp fragment of the $16 \mathrm{~S}$ rDNA was amplified using forward primer $27 \mathrm{f}$ ( 5 '-AGAGTTTGATCCTGGCTCAG-3') and reverse primer 1512r (5'-ACGGCTACCTTGTTACGACT-3'; Devereux and Wilkinson, 2004). The PCR products were sequenced using an ABI3730 XL automatic DNA sequencer. The sequences were then compared with the Gen-Bank database using the BLAST algorithm (National Center for Biotechnology Information, Bethesda, MD).

\section{Maize Ensilage in Experimental Silos}

The LAB strains that exhibited the best results, including greater growth rates during fermentation, efficiency in reducing the $\mathrm{pH}$, an ability to inhibit yeasts, E. coli, B. cereus, and the reference pathogens (C. perfringens and L. monocytogenes), had the best profile of VFA and lactic acid production, and the lowest ethanol production, were selected for evaluation on maize silage in PVC experimental silos. The maize, approximately 102 to $119 \mathrm{~d}$ old, was harvested in the rainy season using a self-propelled harvester with the particle size set to $10 \mathrm{~mm}$. Inoculants were previously prepared according to Ávila et al. (2009), mixed with $80 \mathrm{~mL}$ of distilled water, and homogenized on $3 \mathrm{~kg}$ of forage to be ensiled, 
resulting in an inoculant application rate of $6 \log \mathrm{cfu} / \mathrm{g}$ of forage. In the control treatment, only distilled water $(80 \mathrm{~mL})$ was added to the forage.

Forage was ensiled in experimental PVC silos $10 \mathrm{~cm}$ in diameter and $60 \mathrm{~cm}$ in height, adapted with Bunsentype valves with an average compaction density of 628 $\mathrm{kg}$ of forage $/ \mathrm{m}^{3}$. Forage was manually compacted in the silos, which were sealed, weighted, and stored in a covered area. After $60 \mathrm{~d}$ of ensiling, the full silos were weighed and opened. The loss of DM was calculated using weights of the DM content of the fresh forage and silage.

\section{Chemical Analyses}

Samples were removed from fresh forage and from silages after $60 \mathrm{~d}$ of fermentation. One of the samples was weighed and dried in a fan-assisted oven at $55^{\circ} \mathrm{C}$ for 72 $\mathrm{h}$; another sample was used to make a water extract to determine the $\mathrm{pH}$ value, evaluate the microbial population, and detect fermentation end products. The dried samples were ground in a Willey-type grinder using a 30-mesh sieve and stored in labeled plastic containers. The samples were analyzed for DM content (AOAC, 1990), water-soluble carbohydrates (WSC) by the phenol method (Dubois et al., 1956), CP (AOAC, 1990), and NDF according to Pell and Schofield (1993).

A 25-g sample of fresh forage or maize silage was blended in $225 \mathrm{~mL}$ of $0.1 \%$ sterile peptone water and homogenized in an orbital mixer for $20 \mathrm{~min}$; the $\mathrm{pH}$ of each sample was then determined. Water extracts $(2$ $\mathrm{mL}$ ) were acidified with $10 \mu \mathrm{L}$ of $50 \% \mathrm{H}_{2} \mathrm{SO}_{4}$ ( $\mathrm{vol} / \mathrm{vol}$ ) and frozen before analysis for fermentation end products (Canale et al., 1984). Water-acidified extracts were analyzed for lactic acid, acetic acid, propionic acid, acid butyric, 1,2-propanediol, and ethanol by HPLC (Shimadzu model LC-10Ai; Shimadzu Corp.) as described before.

\section{Microbiological Analyses}

The other portion of water extracts was used for enumeration of microorganisms. Sequential 10-fold dilutions were prepared to quantify the microbial groups. Yeasts and filamentous fungi were enumerated on dichloran rose bengal chloramphenicol medium (Difco; Becton Dickinson, Sparks, MD). The plates were incubated at $28^{\circ} \mathrm{C}$ for $72 \mathrm{~h}$. Yeasts were distinguished from filamentous fungi by colony appearance and cell morphology. For enumeration of LAB, pour plating onto de Man, Rogosa, Sharpe agar (M641I, Himedia) plus nystatin $(4 \mathrm{~mL} / \mathrm{L})$ was used. The plates were incubated at $30^{\circ} \mathrm{C}$ for $72 \mathrm{~h}$. Colonies were counted on plates containing a minimum of 30 and a maximum of $300 \mathrm{cfu}$.
The quantification of Clostridium spp. was performed in reinforced clostridial agar (Himedia) medium, and the plates were incubated for $7 \mathrm{~d}$ at $37^{\circ} \mathrm{C}$ in an anaerobic chamber. The nutrient agar medium (Himedia) was used for counting Bacillus spp., and the plates were incubated at $37^{\circ} \mathrm{C}$ for $24 \mathrm{~h}$ under aerobic conditions. Samples for counting Bacillus spp. and Clostridium spp. were previously pasteurized at $80^{\circ} \mathrm{C}$ for $10 \mathrm{~min}$ to kill vegetative bacterial cells leaving only endospores.

To evaluate the presence of Listeria spp., Oxford medium (Himedia) was used after a primary enrichment of samples in a buffered Listeria-enrichment broth (M569, Himedia), and the plates were incubated at $30^{\circ} \mathrm{C}$ for 24 $\mathrm{h}$. The verification of the presence of Listeria spp. was performed according to Unites States FDA methods (Hitchins and Jinneman, 2011), and the confirmation of the genus was performed using a Gram stain preliminary test, with catalase and motility tests using an API Listeria Kit (bioMérieux, Marcy l'Etoile, France) for the final confirmation. The count of microorganisms of the family Enterobacteriaceae was performed through violet red bile glucose agar (Difco), and quantification was conducted after $24 \mathrm{~h}$ of incubation at $37^{\circ} \mathrm{C}$.

\section{Aerobic Stability}

After silo opening, samples of approximately $3 \mathrm{~kg}$ were removed from each minisilo and placed in plastic buckets to assess the aerobic stability. Temperatures were measured each 30 min using data loggers (model MI-IN-D-2-L; Impac, São Paulo, Brazil) inserted into the silage mass at a depth of $10 \mathrm{~cm}$. The aerobic stability was defined as the number of hours the silage remained stable before rising more than $2^{\circ} \mathrm{C}$ above the ambient temperature $\left(25.6^{\circ} \mathrm{C}\right.$; Kung et al., 2003).

\section{Statistical Analyses}

The metabolite production data of 65 strains that showed better growth and efficiency in reducing the $\mathrm{pH}$ of the aqueous extract were evaluated by the principal component analysis using the XL Stat software (version 7.5; Addinsoft, New York, NY). The experiment was carried out in a completely randomized design with 10 treatments (9 LAB strains and a control without inoculants) and 3 replicates. The statistical analysis was performed using the SISVAR (Lavras, Brazil) software, version 4.5.

\section{RESULTS}

\section{Selection of Bacterial Strains for Inoculants}

At $48 \mathrm{~h}$, the growth of LAB strains (measured in absorbance units) and decrease in the $\mathrm{pH}$ values in maize 
extract varied between the different strains from 0.135 to 0.423 and from 1.18 to 2.37 , respectively. Of the 75 LAB strains tested, 65 strains were assessed regarding metabolite production. The UFLA SLM04, UFLA SLM05, UFLA SLM16, UFLA SLM17, UFLA SLM38, UFLA SLM109, UFLA SLM110, UFLA SLM111, UFLA SLM112, and UFLA SLM113 strains were discarded in the selection process because their growth in the maize extract was less intense, resulting in greater $\mathrm{pH}$ values compared with other strains.

From the 65 total LAB strains, only the UFLA SLM12, UFLA SLM84, UFLA SLM85, UFLA SLM86, and UFLA SLM100 strains exhibited an antagonistic relationship with $C$. perfringens, causing the formation of a small inhibition halo with sizes between 3 and 5 $\mathrm{mm}$. For the other pathogenic or deteriorative microorganisms tested, no inhibition halo was formed.

Differences regarding metabolite production in the maize extract were observed between the strains assessed. The strains exhibited production of lactic and acetic acids ranging from 0.16 to 0.62 and from 0.10 to $0.22 \mathrm{~g} / \mathrm{L}$, respectively. All LAB strains produced small quantities of propionic acid, which varied from 0.06 to $0.12 \mathrm{~g} / \mathrm{L}$; however, the strain UFLA SLM06 stood out due to its greater production of this compound $(0.22$ $\mathrm{g} / \mathrm{L})$ and acetic acid $(0.25 \mathrm{~g} / \mathrm{L})$. All strains had low ethanol production (from $0.02-0.05 \mathrm{~g} / \mathrm{L}$ ), with the exception of UFLA SLM100, which exhibited an ethanol productivity of approximately $0.81 \mathrm{~g} / \mathrm{L}$. None of the assessed strains produced 1,2-propanediol.

In the principal component analysis (Figure 1), the first 2 components (PC1 and PC2) explain $54.03 \%$ of the total variance. The strains that correlated with acetic acid, in the left upper quadrant, also correlated with propionic acid. Some strains correlated only with lactic acid (right lower quadrant), and others with ethanol (left lower quadrant). Strains present in the right upper quadrant did not correlate with any of the metabolites desired in the silage and were discarded in the selection process. Strains related to an increase in the production of lactic acid (UFLA SLM08, UFLA SLM41, UFLA SLM46, and UFLA SLM105), acetic acid (UFLA SLM06, UFLA SLM11, and UFLA SLM103), propionic acid (UFLA SLM06, UFLA SLM11, UFLA SLM45, UFLA SLM46, UFLA SLM103, UFLA SLM105, and UFLA SLM108), and those that produced lower levels of ethanol (UFLA SLM08, UFLA SLM46, and UFLA SLM108) were selected to be evaluated in PVC experimental silos.

\section{Molecular Identification of the $L A B$}

The results of the sequencing of the $16 \mathrm{~S}$ region of rRNA of the LAB species selected to be evaluated in experimental silos identified Leuconostoc mesenteroides, Lactobacillus plantarum, and L. buchneri (Table 1).

\section{Maize Ensilage in Experimental Silos}

The DM, CP, and NDF content, as well as the DM loss, were not influenced $(P>0.05)$ by the inoculation of LAB strains and showed similar values in the different silages (Table 2). During the fermentation process, a reduction was observed in the DM content, from 355.94 to $342.30 \mathrm{~g} / \mathrm{kg}$. Conversely, the NDF content and DM loss increased, from 569.20 to $585.61 \mathrm{~g} / \mathrm{kg}$ of $\mathrm{DM}$ and from 0 to $5.53 \%$ (Table 2).

Differences were observed for $\mathrm{pH}$ value and WSC among the silages $(P<0.01)$. Silages inoculated with UFLA SLM11 and UFLA SLM103 strains identified as L. buchneri showed a smaller reduction in $\mathrm{pH}$ values, with values of 4.16 and 4.14, respectively; whereas the other silages inoculated and the control treatment presented $\mathrm{pH}$ values below 4.09. Silages inoculated with the UFLA SLM 46 and 105 strains identified as $L$. plantarum and with strain UFLA SLM108 (L. buchneri) presented the lowest concentrations of WSC, with values of $4.28,4.53$, and $3.51 \mathrm{~g} / \mathrm{kg}$ of $\mathrm{DM}$, respectively. Concentrations of WSC were higher than $6.12 \mathrm{~g} / \mathrm{kg}$ of DM for the other silages evaluated (Table 2).

A significant difference of lactic acid concentration was observed among the silages analyzed $(P=0.02)$ (Table 2); however, using the Scott-Knott test, it was not possible to detect these differences. This can be explained by the high coefficient of variation (21\%) found for this variable. The lactic acid concentration at the end of the $60 \mathrm{~d}$ of fermentation ranged from $29.72 \mathrm{~g} / \mathrm{kg}$ of DM for the silage control to $69.49 \mathrm{~g} / \mathrm{kg}$ of DM in silage inoculated with the UFLA SLM08 ( $L$. plantarum) strain.

A significant difference was found between treatment for the concentration of acetic acid $(P<0.01)$ and 1,2-propanediol $(P<0.001 ;$ Table 2$)$. The silage inoculated with UFLA SLM11 (L. buchneri) showed greater concentrations of acetic acid, followed by silages inoculated with UFLA SLM08 (L. plantarum), UFLA SLM103, and UFLA SLM108 strains (identified as L. buchneri). The other treatments presented similar results for acetic acid (Table 2). The concentration of 1,2-propanediol was observed only in silages inoculated with the UFLA SLM11, UFLA SLM103, and UFLA SLM108 strains, identified as L. buchneri, with greater concentrations in silage inoculated with UFLA SLM11.

No significant differences were found between treatments for the concentration of propionic $(P=0.27)$ and butyric $(P=0.36)$ acids of the silages, with mean values of 3.96 and $1.37 \mathrm{~g} / \mathrm{kg}$ of DM for fresh forage and 4.56 and $0.99 \mathrm{~g} / \mathrm{kg}$ of $\mathrm{DM}$ for silage after $60 \mathrm{~d}$ of fer- 


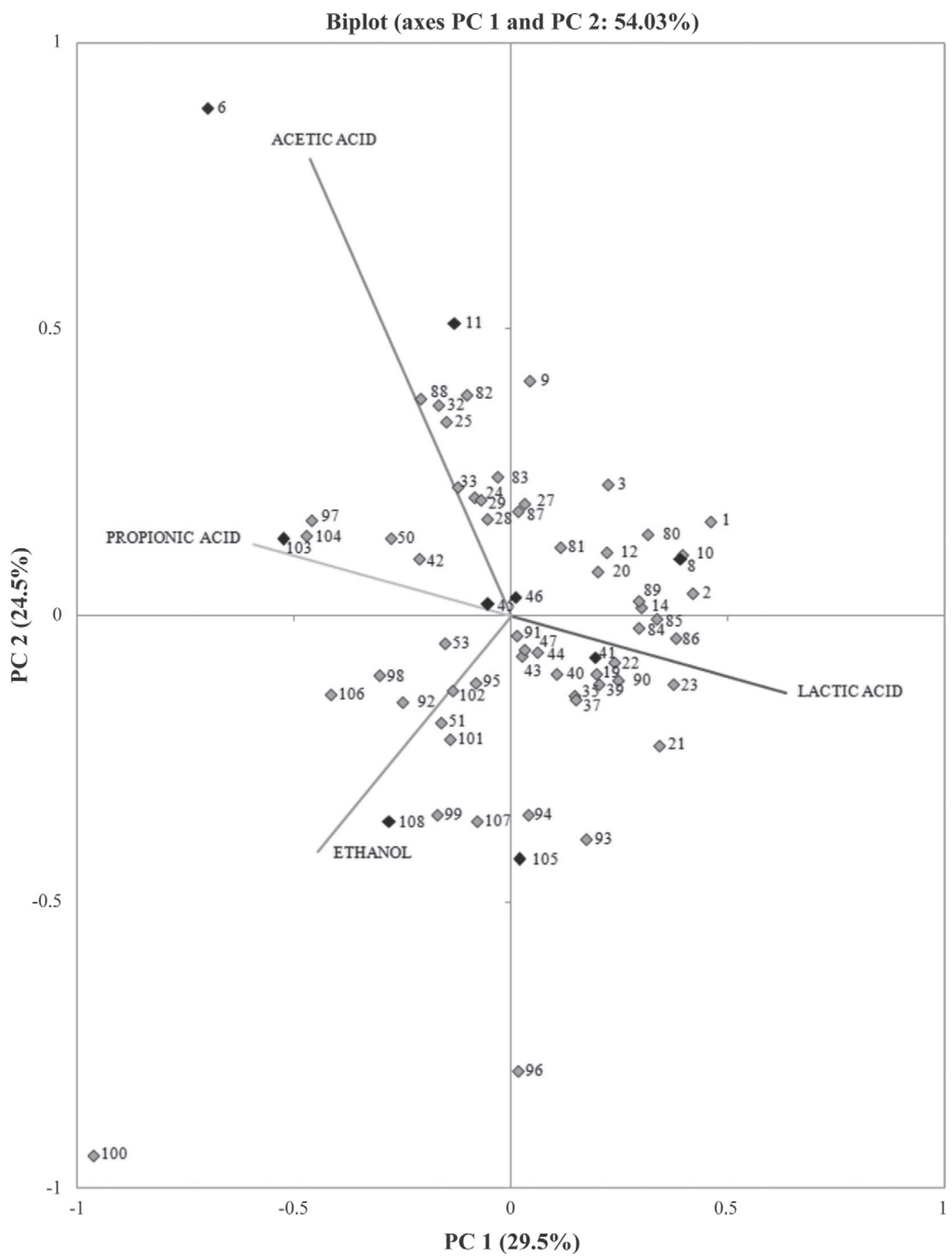

Figure 1. Principal component (PC) analysis of the products of metabolism of lactic acid bacteria evaluated.

mentation, respectively. The ethanol concentration was not different among the silages evaluated $(P=0.21)$, which presented an average concentration of $29.61 \mathrm{~g} /$ $\mathrm{kg}$ of DM.

No differences were found $(P>0.05)$ among inoculated silages for the counts of yeasts, filamentous fungi, enterobacteria, Bacillus spp., or Clostridium spp. (Figure 2). However, the yeasts, filamentous fungi, and Enterobacteriaceae population was numerically greater in forages than silages, and the Bacillus spp. and Clostridium spp. populations was numerically greater in silages than forages. 
Table 1. Molecular identification of lactic acid bacteria (LAB) strains

\begin{tabular}{lllc}
\hline LAB strain & BLAST alignment & Code at NCBI & Identity $(\%)$ \\
\hline UFLA SLM 06 & Leuconostoc mesenteroides & HQ450732.1 & 97 \\
UFLA SLM 08 & Lactobacillus plantarum & AB617650.1 & 97 \\
UFLA SLM 11 & Lactobacillus buchneri & HM162412.1 & 98 \\
UFLA SLM 41 & L. plantarum & HM218291.1 & 99 \\
UFLA SLM 45 & L. plantarum & HM218291.1 & 98 \\
UFLA SLM 46 & L. plantarum & HM218291.1 & 98 \\
UFLA SLM 103 & L. buchneri & HM218291.1 & 98 \\
UFLA SLM 105 & L. plantarum & CP002652.1 & 98 \\
UFLA SLM 108 & L. buchneri & & 98 \\
\hline
\end{tabular}

The LAB population after fermentation was different $(P<0.001)$ for silages without inoculants and those inoculated with different strains (Figure 3). In fresh forage, the LAB population was 100 times greater than the application rate $(6 \mathrm{log} \mathrm{cfu} / \mathrm{g})$, which could be explained by the interval between inoculation and microbiological analysis $(6 \mathrm{~h})$. However, after $60 \mathrm{~d}$ of fermentation, the LAB population was greater in silages inoculated with the UFLA SLM11 (L. buchneri), then silages inoculated with UFLA SLM06 (Leuconostoc mesenteroides), UFLA SLM103, and UFLA SLM108 (L. buchneri) strains. In all silages assessed and in the control treatment, a reduction in the LAB population with fermentation was observed, with the exception of the treatment inoculated with the UFLA SLM11 ( $L$. buchneri) strain, in which the opposite result was found.

The presence or absence of Listeria spp. was assessed according to resolution number 12 of the Collegiate Board of Directors of the Brazilian Health Surveillance Agency - Agência de Vigilância Sanitária (Ministério da Saúde, 2001). The presence of Listeria spp. was detected in fresh forage, control silages, and silages inoculated with L. buchneri (UFLA SLM11, UFLA SLM103, and UFLA SLM108 strains) and L. plantarum (UFLA SLM41, UFLA SLM46, and UFLA SLM105 strains). The presence of Listeria spp. was not found in other silages.

Isolates that exhibited characteristics inherent to the genus Listeria - gram positive, catalase activity, and positive motility - were subjected to biochemical identification using an API Listeria kit (BioMeriéux). On fresh forage and on silages inoculated with the UFLA SLM46 and UFLA SLM105 (L. plantarum) strains, the nonpathogenic species Listeria seeligeri and Listeria welshmeri were identified. The species L. monocytogenes and Listeria innocua were identified on fresh forage, control silages, and on silages inoculated with the UFLA SLM11, UFLA SLM103, UFLA SLM108 ( $L$. buchneri), and UFLA SLM41 and UFLA SLM46 ( $L$. plantarum) strains. However, it was not possible to differentiate between $L$. monocytogenes and L. innocua. In silage inoculated with the UFLA SLM108 (L. buchneri) strain, the species Listeria ivanovii was identified.

\section{Evaluation of Aerobic Stability}

The increase in temperature in the experimental silages began after approximately $6 \mathrm{~h}$ of air exposure, and inoculated silages showed a slower temperature increase than the control silage during the initial evaluation period (Figure 4). In silage inoculated with the UFLA SLM103 (L. buchneri) strain, a dramatic increase in temperature occurred only after approximately $25 \mathrm{~h}$ of aerobic exposure (Figure 4). No differences $(P>$ $0.05)$ were found between the maximum temperatures reached and the time required achieving this temperature (Figure 5) and for data on the loss of aerobic stability in the different treatments (Figure 6).

\section{DISCUSSION}

For most of the strains assessed, it was possible to observe a correlation between growth, through absorbance readings, and the reduction in the $\mathrm{pH}$ of the medium. The correlation between these 2 factors is explained by the production of acids by LAB (McDonald et al., 1991). Saarisalo et al. (2007), selecting LAB strains for the ensiling of meadow fescue (Festuca pratensis) and timothy (Phleum pratense), found results contrary to the present study, in that strains that showed rapid growth were not the most effective in $\mathrm{pH}$ reduction, although the growth rate at the end of the fermentation period was satisfactory. Therefore, besides the decrease in $\mathrm{pH}$, the evaluation of the metabolites formed is a key for selecting inoculants.

The assessment of antibacterial activity as a way to select strains for ensiling was not efficient. The UFLA SLM12, UFLA SLM84, UFLA SLM85, UFLA SLM86, and UFLA SLM100 strains demonstrated antimicrobial activity against Clostridium spp. However, these strains were not selected for the ensilage process because they did not have good growth in maize aqueous extract, had lower metabolite (volatile fat and lactic acids) production, and higher ethanol concentrations.

The antimicrobial activity of LAB is primarily related to the production of organic acids. The antimicrobial 

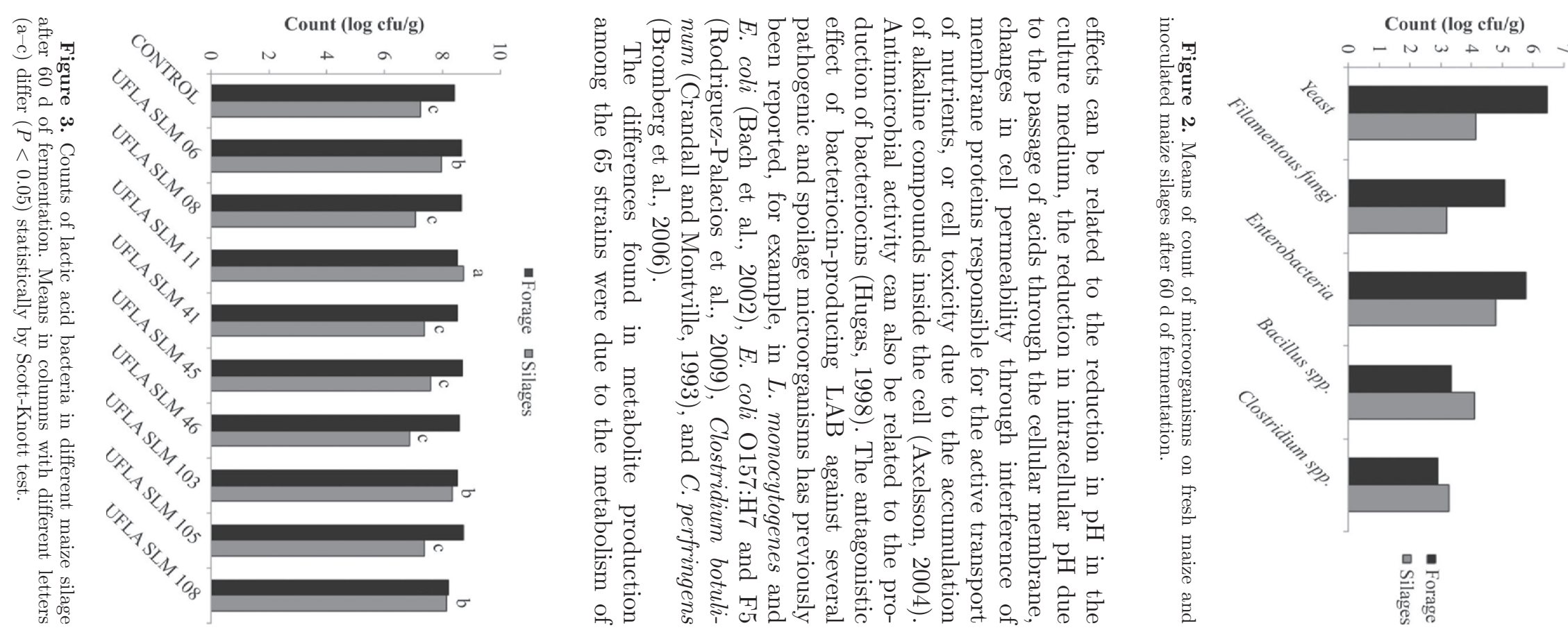

Table 2. Chemical composition of fresh maize and maize silage inoculated with lactic acid bacteria strains after $60 \mathrm{~d}$ of fermentation

\begin{tabular}{|c|c|c|c|c|c|c|c|c|c|c|c|c|c|}
\hline \multirow[b]{2}{*}{ Variable } & \multirow[b]{2}{*}{ Forage } & \multirow[b]{2}{*}{$\begin{array}{l}\text { Average } \\
\text { silages }\end{array}$} & \multicolumn{10}{|c|}{ Silages } & \multirow[b]{2}{*}{$P$-value } \\
\hline & & & Control & $\begin{array}{c}\text { UFLA } \\
\text { SLM } 06\end{array}$ & $\begin{array}{c}\text { UFLA } \\
\text { SLM } 08\end{array}$ & $\begin{array}{c}\text { UFLA } \\
\text { SLM } 11\end{array}$ & $\begin{array}{c}\text { UFLA } \\
\text { SLM } 41\end{array}$ & $\begin{array}{c}\text { UFLA } \\
\text { SLM } 45\end{array}$ & $\begin{array}{c}\text { UFLA } \\
\text { SLM } 46\end{array}$ & $\begin{array}{c}\text { UFLA } \\
\text { SLM } \\
103\end{array}$ & $\begin{array}{c}\text { UFLA } \\
\text { SLM } \\
105\end{array}$ & $\begin{array}{c}\text { UFLA } \\
\text { SLM } \\
108\end{array}$ & \\
\hline $\mathrm{pH}$ & 4.19 & 4.07 & $4.06^{\mathrm{b}}$ & $4.04^{\mathrm{b}}$ & $4.02^{\mathrm{b}}$ & $4.16^{\mathrm{a}}$ & $4.05^{\mathrm{b}}$ & $4.03^{\mathrm{b}}$ & $4.09^{\mathrm{b}}$ & $4.14^{\mathrm{a}}$ & $4.03^{\mathrm{b}}$ & $4.06^{\mathrm{b}}$ & $<0.01$ \\
\hline $\mathrm{DM}(\mathrm{g} / \mathrm{kg})$ & 355.94 & 342.30 & 341.16 & 342.01 & 342.94 & 332.62 & 343.13 & 342.53 & 344.77 & 346.14 & 343.92 & 343.76 & 0.97 \\
\hline Loss of DM (\% of DM) & & 5.53 & 6.09 & 4.58 & 4.84 & 7.89 & 4.67 & 5.64 & 4.42 & 4.58 & 6.21 & 6.39 & 0.86 \\
\hline \multicolumn{14}{|l|}{ Concentration ( $\mathrm{g} / \mathrm{kg}$ of $\mathrm{DM})$} \\
\hline $\mathrm{CP}$ & 69.15 & 69.87 & 67.09 & 65.89 & 70.19 & 66.07 & 71.35 & 68.98 & 76.69 & 70.87 & 66.49 & 75.04 & 0.39 \\
\hline Water-soluble carbohydrates & 68.17 & 6.34 & $6.76^{\mathrm{a}}$ & $6.12^{\mathrm{a}}$ & $6.17^{\mathrm{a}}$ & $7.77^{\mathrm{a}}$ & $9.09^{\mathrm{a}}$ & $7.43^{\mathrm{a}}$ & $4.29^{\mathrm{b}}$ & $7.68^{\mathrm{a}}$ & $4.53^{\mathrm{b}}$ & $3.51^{\mathrm{b}}$ & $<0.01$ \\
\hline NDF & 569.20 & 585.61 & 561.07 & 569.92 & 564.87 & 610.45 & 594.97 & 581.40 & 595.32 & 620.01 & 574.67 & 583.40 & 0.50 \\
\hline Lactic acid & 8.93 & 47.88 & 29.72 & 47.18 & 69.49 & 41.21 & 55.11 & 47.37 & 50.83 & 30.80 & 62.99 & 44.13 & 0.02 \\
\hline Acetic acid & 2.10 & 6.15 & $3.25^{\mathrm{c}}$ & $5.83^{\mathrm{c}}$ & $7.20^{\mathrm{b}}$ & $10.47^{\mathrm{a}}$ & $5.12^{\mathrm{c}}$ & $4.62^{\mathrm{c}}$ & $4.95^{\mathrm{c}}$ & $7.29^{\mathrm{b}}$ & $5.78^{\mathrm{c}}$ & $7.07^{\mathrm{b}}$ & $<0.01$ \\
\hline Propionic acid & 3.96 & 4.56 & 2.61 & 3.78 & 6.19 & 4.49 & 5.40 & 4.60 & 4.50 & 4.36 & 5.88 & 3.79 & 0.27 \\
\hline Butyric acid & 1.37 & 0.99 & 0.78 & 0.58 & 2.22 & 2.19 & 1.16 & 0.44 & 0.41 & 0.56 & 0.84 & 0.74 & 0.36 \\
\hline 1,2-propanediol & $\mathrm{ND}^{1}$ & 0.004 & $\mathrm{ND}^{\mathrm{c}}$ & $\mathrm{ND}^{\mathrm{c}}$ & $\mathrm{ND}^{\mathrm{c}}$ & $0.02^{\mathrm{a}}$ & $\mathrm{ND}^{\mathrm{c}}$ & $\mathrm{ND}^{\mathrm{c}}$ & $\mathrm{ND}^{\mathrm{c}}$ & $0.01^{\mathrm{b}}$ & $\mathrm{ND}^{\mathrm{c}}$ & $0.01^{\mathrm{b}}$ & $<0.001$ \\
\hline Ethanol & 10.16 & 29.61 & 18.39 & 26.60 & 42.38 & 27.48 & 31.84 & 29.32 & 33.33 & 23.12 & 38.26 & 25.42 & 0.21 \\
\hline
\end{tabular}

${ }^{\mathrm{a}-\mathrm{c}}$ Means in columns with different letters differ $(P<0.05)$ statistically by Scott-Knott test.

$\vec{N}{ }^{1}$ Not detected. 


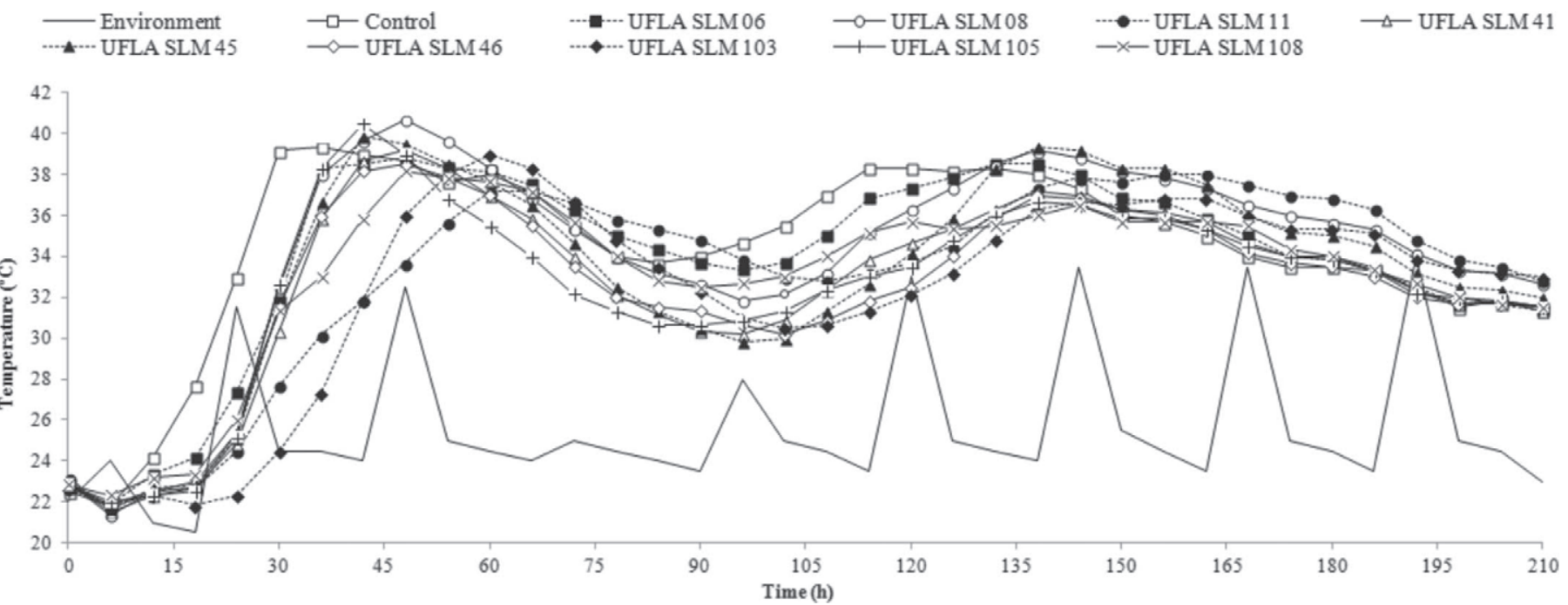

Figure 4. Variation in temperature during aerobic exposure of silages; control and inoculated silage with strains of lactic acid bacteria.

the bacteria. Lactic acid bacteria can be classified as homofermentative, producing almost exclusively lactic acid on hexoses, and heterofermentatives that, besides lactic acids, also produce acetic acid, ethanol, and carbon dioxide as products of the fermentation of hexoses and pentoses (Axelsson, 2004). Fermentation of pentoses results in both lactic and acetic acids in equal molar proportions by both facultative and obligate heterofermenters. Obligate homofermenters cannot ferment pentoses, but those species are much less common in silages.

Strains that exhibited high production of lactic acid were identified as facultative heterofermentatives belonging to the species L. plantarum (UFLA SLM08, UFLA SLM41, UFLA SLM46, and UFLA SLM105 strains), whereas strains that produced acetic acids were obligate heterofermentatives of the species $L$. buchneri (UFLA SLM11 and UFLA SLM103 strains) and Leuconostoc mesenteroides (UFLA SLM06). Leuconostoc mesenteroides (UFLA SLM06) produced high concentrations of propionic and acetic acids. According to Moon (1983), propionic and acetic acids show a synergistic effect that is able to reduce the growth of yeasts and filamentous fungi and can increase the aerobic stability of silage. When silage $\mathrm{pH}$ is below 4.73 , acetic acid is primarily in its undissociated form. In this form, the membranes of yeasts and filamentous fungi become permeable to the acetic acid. Within the cell, the acid is dissociated $\left(\mathrm{RCOO}^{-}+\mathrm{H}^{+}\right)$due to the $\mathrm{pH}$ being close to 7.0, releasing $\mathrm{H}^{+}$ions, which reduce the intracellular pH (McDonald et al., 1991; Davidson, 2007).

After fermentation, reduction in $\mathrm{pH}$ values and in DM and WSC contents were observed, primarily due to LAB metabolism, which consumes carbohydrates and produces lactic acid, thus contributing to the decrease in $\mathrm{pH}$ values in addition to the production of

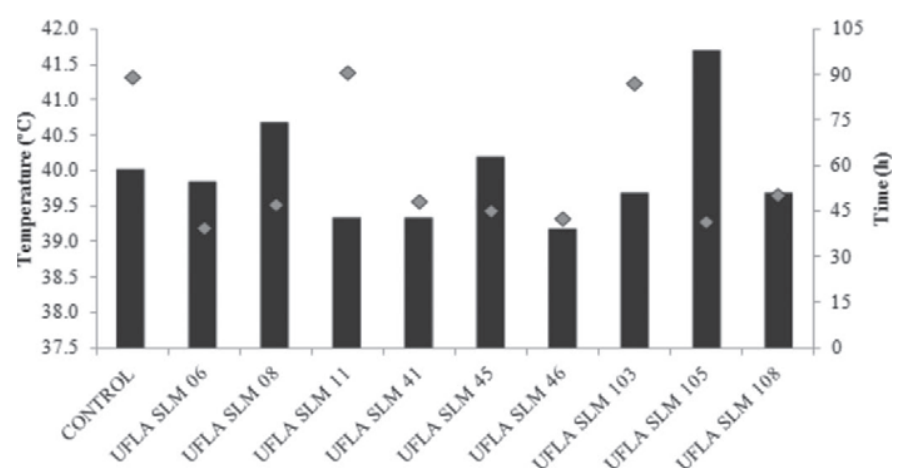

Figure 5. Maximum temperature achieved (black bars) and the time required to achieve it (gray diamonds) for different treatments after $7 \mathrm{~d}$ of aerobic exposure.

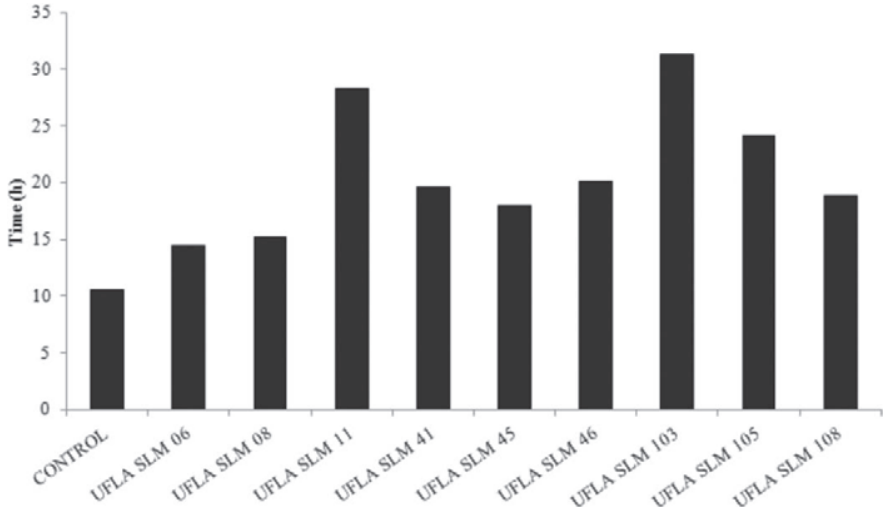

Figure 6. Aerobic stability of maize silages inoculated with strains of lactic acid bacteria. 
$\mathrm{CO}_{2}$ (McDonald et al., 1991). The intensity with which these alterations occur is an indication of the fermentation quality of the silage. The lower concentrations of residual WSC in the silage inoculated with the UFLA SLM46 and UFLA SLM105 strains identified as $L$. plantarum and with the UFLA SLM108 (L. buchneri) strain showed that these strains were less efficient in the utilization of carbohydrates because they did not produce higher lactic and acetic concentrations. The smaller reductions in $\mathrm{pH}$ values were observed in silages inoculated with the UFLA SLM11 and UFLA SLM103 strains, identified as L. buchneri. This result was expected due to the metabolism of the microorganism that produces the lactic acid, acetic acid, ethanol, and $\mathrm{CO}_{2}$ from hexoses and pentoses. These metabolites contribute to a smaller reduction in $\mathrm{pH}$ values; however, under the experimental conditions, the final $\mathrm{pH}$ values were considered adequate for good quality silage (Nkosi et al., 2009; Li and Nishino, 2011).

The NDF contents obtained in the present study increased after $60 \mathrm{~d}$ of fermentation, with values similar to those obtained by Filya and Sucu (2010). According to Ávila et al. (2008), increases in the fibrous fraction of the ensiled material in relation to the original material can be observed as a result of DM losses in the form of gases, which proportionately increases the fiber content of the silages.

The average DM losses in silages were low (5.53\%), which is a characteristic of maize silages. The majority of these losses were most likely due to the fermentation process, with the remainder due to plant and microbial respiration (McDonald et al., 1991). While reviewing scientific studies published between 1990 and 1995, Kung (2009) found that DM losses were reduced with the use of additives in only $35 \%$ of the studies. Kleinschmit and Kung (2006), evaluating the effects of the combined inoculation of L. buchneri 40788 and Pediococcus pentosaceus, found DM losses of approximately $5.3 \%$ for inoculated silages; whereas, in the control treatment, those authors found DM losses of $2.3 \%$, showing that the additive effects on DM losses are variable.

Inoculants did not significantly affect the chemical composition, as can be seen in the DM, CP, and NDF contents. Rodrigues et al. (2004) and Nkosi et al. (2009) found similar results in maize silage using different microbial inoculants. The effect of inoculants was more pronounced on the microbial population and on the metabolites produced during fermentation, as can be observed by significant differences among the silage evaluated for the concentrations of lactic and acetic acids, 1,2-propanediol, $\mathrm{pH}$ values, and for the LAB population.

Under the present experimental conditions, the concentrations of lactic, acetic, propionic, and butyric acids, as well as the ethanol content in fresh forage, were above the levels reported by Filya (2004). Silages inoculated with the UFLA SLM11, UFLA SLM103, and UFLA SLM108 strains, identified as L. buchneri, produced high concentrations of acetic acid; however, the lactic acid concentration was not greater than that of the other silages. These results were expected, as the aforementioned strains were classified as obligate heterofermentatives. In a selection process based on metabolite production in the maize extract, the UFLA SLM11, UFLA SLM103, and UFLA SLM108 strains correlated with the production of acetic or propionic acid and were, therefore, selected, and showed similar results in silages from experimental silos. Bach et al. (2005), evaluating the effects of inoculation of maize silage with L. buchneri, found an increase in the concentration of acetic acid, whereas the concentration of lactic acid was concomitantly reduced.

According to Elferink et al. (2001), the increase in acetic acid content can also be a result of anaerobic conversion of lactic acid into acetic acid and 1,2-propanediol, usually associated with the L. buchneri species. The production of 1,2-propanediol is triggered by the conversion of lactate to lactaldehyde by a lactaldehyde dehydrogenase. The second step of 1,2-propanediol formation is the conversion of lactaldehyde into 1,2-propanediol, which is catalyzed by a putative lactaldehyde reductase (Heinl et al., 2012). According to the proportions of lactic and acetic acids and 1,2-propanediol found in silages inoculated with the UFLA SLM11, UFLA SLM103, and UFLA SLM108 strains, we can infer that such conversion does occur.

The average concentrations of propionic acid in all inoculated silages were greater than those reported by Filya (2004) and Filya and Sucu (2010), but were similar to the results found by $\mathrm{Li}$ and Nishino (2011) in maize silages inoculated with L. buchneri after $120 \mathrm{~d}$ of fermentation. In silages, the 1,2-propanediol can be converted into propionic acid by Lactobacillus diolivorans LAB (Krooneman et al., 2002); however, silages inoculated with the UFLA SLM11, UFLA SLM103, and UFLA SLM108 strains did not exhibit the greatest content of propionic acid, likely due to the absence of the association between L. buchneri and L. diolivorans. The strains evaluated in the present study were not efficient in reducing the butyric acid content of silages compared with the control; however, all silages showed butyric acid concentrations below $2.2 \mathrm{~g} / \mathrm{kg}$ of DM. This value was above the value normally observed in maize silages (Saarisalo et al., 2007; Tabacco et al., 2009), but reflects Clostridium activity during fermentation.

The presence of ethanol in silage is undesirable because it is an indicative of yeast growth and DM loss. The use of inoculants did not alter significantly any of 
these characteristics. Despite this compound being an energy source for ruminants (Kristensen et al., 2007), yeasts compete with LAB for substrates, and the ethanol formed does not contribute to silage preservation, contrary to that provided by lactic, acetic, and propionic acids.

Of the 9 strains tested in experimental silos, a correlation between the metabolites produced in the preselection and silage was observed for 5 of them. The strains related to the increased production of lactic (UFLA SLM08, UFLA SLM41, and UFLA SLM105) and acetic acids (UFLA SLM11 and UFLA SLM103) in aqueous extracts also showed greater concentrations of these acids after the ensiling process. A correlation between the concentrations of ethanol and propionic acid in the preselection process and after ensiling was not observed; thus, strains that produce a particular metabolite do not always show the same characteristics during ensiling.

In the process of preselection, the UFLA SLM06 ( Leuconostoc mesenteroides) strain was the most correlated with the production of acetic acid; however, it was not observed in the silage. This low acetic acid production by the UFLA SLM06 strain may have contributed to the lower aerobic stability observed. The strain UFLA SLM108 (L. buchneri) was selected based on high production of propionic acid, its effectiveness in reducing the $\mathrm{pH}$ of the medium, and good growth in the maize aqueous extract. However, during the fermentation process, this strain did not stand out compared with the other strains of the same species (UFLA SLM11 and UFLA SLM103), as it did not present high yields of the metabolites in the silage, which contributed to a lower aerobic stability. A probable explanation is the strains' ability to adapt to substrates, exhibiting different phenotypic expressions from a single genome from which bacteria of the same species can express different enzymatic activities, which can influence the ability to use different substrates (Sohier et al., 1999). Furthermore, using the classical microbiological methodology, it was not possible to know if the inoculated LAB survived the ensiling process and if they effectively used the available substrate and produced the expected metabolites.

The addition of inoculants significantly affected the LAB population, but not the other group of microorganisms assessed. Lactic acid bacteria are the microorganisms that most affect silage fermentation by producing the major acids responsible for its preservation. The largest LAB populations were observed in silages inoculated with the UFLA SLM11 strain. These results might have been due to the ability of this strain to survive during the fermentation process, as an increase in the population of LAB in silage was observed compared with the forage. In the present study, a difference was noted between the concentrations of acetic acid in silages with different inoculants, but this result was not reflected in the population of undesirable microorganisms. A possible explanation is that the evaluation was only performed at the beginning of the process and after $60 \mathrm{~d}$ of fermentation, when the silage was already stable.

The reduction in the yeast, filamentous fungi, and enterobacteria populations throughout the fermentation process of the ensiled mass are likely due to the environmental conditions becoming less favorable for the development of these microorganisms. The concentrations of acetic and propionic acids observed after fermentation were greater than the minimum inhibitory concentration against these microorganisms. Nishino (2011) reported that the minimum inhibitory concentration of lactic acid against yeasts and filamentous fungi is $50 \mathrm{~g} / \mathrm{L}$, which is equivalent to $115 \mathrm{~g} / \mathrm{kg}$ of DM in silages with a DM content of approximately 300 $\mathrm{g} / \mathrm{kg}$. The minimum inhibitory concentration of acetic and propionic acids against yeasts and filamentous fungi was approximately 10 to 20 times lower than that of lactic acid, thus showing a greater antagonistic effect due to acetic and propionic acids compared with lactic acid.

The increases in the populations of Bacillus spp. and Clostridium spp. during the fermentative process possibly occurred because they are facultative aerobic and anaerobic microorganisms, respectively. Therefore, the growth of the previously mentioned microorganisms is more intense when these conditions are established inside the silo. Moreover, Bacillus spp. and Clostridium spp. can sporulate under adverse conditions, surviving the process. Bacillus spp. are able to ferment a wide variety of carbohydrates into organic acids, ethanol, 2,3-butanediol, and glycerol. In addition to these compounds having no effect on silage preservation, these bacteria compete with LAB for substrates (Giffel et al., 2002). The presence of Clostridium spp. in the evaluated silages possibly occurred in areas with the onset of aerobic deterioration, as the chemical conditions of the silage (DM above $30 \%$ and reduced $\mathrm{pH}$ ) were unfavorable for the growth of this microorganism according to Borreani et al. (2002). No data were found on the spore count of Clostridium and Bacillus in maize silage in a tropical climate. Rossi and Dellaglio (2007), analyzing the quality of silage in Italy, also verified the presence of Clostridium spp. in maize and alfalfa silages.

In all silages assessed and in the control treatment, we found a reduction in the LAB population after the fermentation period, with the exception of the treatment inoculated with L. buchneri (UFLA SLM11 strain). In the selection process of inoculant strains, it is very important to consider the survival of the selected strain 
until the end of the fermentation process, which can also improve the aerobic stability of silages.

The growth and survival of Listeria spp. in silage are determined by the degree of anaerobiosis and the $\mathrm{pH}$ of the silage (Elferink et al., 2001). These bacteria can tolerate $\mathrm{pH}$ values ranging from 3.8 to 4.2 for long periods if oxygen is present, even at low levels, which may have contributed to the survival of Listeria spp. in the treatments in which they were found. Vilar et al. (2007) detected Listeria spp. in $33.7 \%$ of maize silage samples, whereas L. monocytogenes species was present in $6 \%$ of these samples, and the species $L$. innocua, $L$. welshimeri, and L. seeligeri were found in 19.3, 4.8, and $1.2 \%$ of the samples assessed, respectively.

Both L. monocytogenes and L. ivanovii are associated with infections in humans and animals and can cause abortions in ruminants and are capable of being transmitted to humans through milk (Czuprynski et al., 2010). According to the literature, the present study is the first to report the presence of these bacteria in maize silages in a tropical climate. Silages inoculated with Leuconostoc mesenteroides (UFLA SLM06) and L. plantarum (UFLA SLM08 and 45) did not present Listeria.

The increase in the temperature of the ensiled mass and its maintenance over time are key indicators of aerobic deterioration, reflecting yeast and filamentous fungi growth (Taylor and Kung, 2002). Silages inoculated with L. buchneri (UFLA SLM11 and 103 strains) exhibited the best results after aerobic exposure, indicating less deterioration by microorganisms. The greater aerobic stability may be due to the greater concentrations of acetic acid observed (Moon, 1983). Acetic acid was able to reduce the growth of yeasts and filamentous fungi, thereby providing a greater aerobic stability to silage. It should be noted that treatments inoculated with LAB strains had greater aerobic stability than those observed in the control treatment, thus emphasizing the importance of inoculation with LAB in maize silages.

The addition of L. buchneri bacteria promoted an increase in aerobic stability in the silage, as was previously found (Muck, 2004). Another important fact was the survival of the strain until the end of the fermentation process. The UFLA SLM11 strain provided silages with a greater count of LAB until the end of fermentation, and it is possible that this strain survived for longer in the fermentation process.

\section{CONCLUSIONS}

The UFLA SLM11 and UFLA SLM103 strains, identified as L. buchneri, are considered to be promising sources for use as inoculants in maize silages because they provide silages with better fermentative characteristics and improvements after aerobic exposure. The inhibition of pathogenic and deteriorative microorganisms was not a good parameter for LAB selection. The preselection method based on metabolite production was efficient in the selection of new inoculant strains, with a good correlation with assays in experimental silos. The inoculation of LAB strains in maize silage did not result in differences in the nutritional value or in the population of pathogenic and deteriorative microorganisms. However, further studies are needed to evaluate the efficiency of these strains in large-scale silos.

\section{ACKNOWLEDGMENTS}

The authors thank Brazilian agencies Conselho Nacional de Desenvolvimento Científico e Tecnológico do Brasil (Brasília, DF Brazil), Fundação de Amparo a Pesquisa de Minas Gerais (Belo Horizonte, MG Brazil), and Coordenação de Aperfeiçoamento de Pessoal de Nível Superior (Brasília, DF Brazil), for scholarship and financial support.

\section{REFERENCES}

AOAC. 1990. Official Methods of Analysis. Vol. 1. 15th ed. Association of Official Analytical Chemists, Washington, DC.

Ávila, C. S., J. C. Pinto, M. S. Sugawara, M. S. Silva, and R. F. Schwan. 2008. Qualidade da silagem de cana-de-açúcar inoculada com uma cepa de Lactobacillus buchneri. Acta Sci. Anim. Sci. $30: 255-261$.

Ávila, C. L. S., J. C. Pinto, H. C. P. Figueiredo, and R. F. Schwan. 2009. Effects of an indigenous and a commercial Lactobacillus buchneri strain on quality of sugar cane silage. Grass Forage Sci. 64:384-394.

Ávila, C. L. S., A. R. Valeriano, J. C. Pinto, H. C. P. F. Figueiredo, A. V. Rezende, and R. F. Schwan. 2010a. Chemical and microbiological characteristics of sugarcane silages treated with microbial inoculants. Braz. J. Anim. Sci. 39:25-32.

Ávila, C. L. S., C. E. C. Bravo-Martins, and R. F. Schwan. 2010b. Identification and characterization of yeasts in sugarcane. J. Appl. Microbiol. 109:1677-1686.

Axelsson, L. 2004. Lactic acid bacteria: Classification and physiology. Pages 1-63 in Lactic Acid Bacteria. S. Salminen and A. Von Wright, ed. Marcel Dekker, New York, NY.

Bach, A., C. Iglesias, C. Adelantando, and M. A. Calvo. 2005. Effectiveness of Lactobacillus buchneri to improve aerobic stability and reducing mycotoxin levels in maize silages under field conditions. Page 232 in Silage Prod. Util. Proc. 19th Int. Silage Conf., Belfast, Northern Ireland. R. S. Park, and M. D. Stronge, ed.

Bach, S. J., T. A. Mcallister, J. Baah, L. J. Yanke, D. M. Veira, V. P. J. Gannon, and R. A. Holley. 2002. Persistence of Escherichia coli O157:H7 in barley silage: Effect of a bacterial inoculant. J. Appl. Microbiol. 93:288-294.

Borreani, G., E. Tabacco, and G. Colombari. 2002. Influenza del deterioramento aeróbico degli insilati sulla qualità dei prodotti caseari. Inf. Agric. 11:58-61.

Bromberg, R., I. Moreno, R. R. Delboni, and H. C. Cintra. 2006. Características da bacteriocina produzida por Lactococcus lactis ssp. hordniae CTC 484 e seu efeito sobre Listeria monocytogenes em carne bovina. Ciênc. Tecnol. Aliment. 26:135-144. 
Canale, A., M. E. Valente, and A. Ciotti. 1984. Determination of volatile carboxylic acids (C1-C5) and acid lactic in aqueous acid extracts of silage by high performance liquid chromatography. J. Sci. Food Agric. 35:1178-1182.

Crandall, A. D., and T. J. Montville. 1993. Inhibition of Clostridium botulinum growth and toxigenesis in a model gravy system by co inoculation with bacteriocin-producing lactic acid bacteria. J. Food Prot. 56:485-488.

Czuprynski, C. J., S. Kathariou, and K. Poulsen. 2010. Listeria. Pages 167-187 in Pathogenesis of Bacterial Infections in Animals. 4th ed. C. L. Gyles, J. F. Prescott, G. Songer, and C. O. Thoen, ed. Wiley-Blackwell, Ames, IA.

Davidson, P. M. 2007. Chemical preservatives and natural antimicrobial compounds. Pages 713-746 in Food Microbiology: Fundamentals and Frontiers. M. P. Doyle, L. R. Beuchat, and T. J. Monteville, ed. Am. Soc. Microbiol., Washington, DC.

Devereux, R., and S. S. Wilkinson. 2004. Amplification of ribosomal RNA sequences. Pages 509-522 in Molecular Microbial Ecology Manual, 2. ed. G. A. Kowalchuk, F. J. de Brujin, I. M. Head, A D. L. Akkermans, and J. D. van Elsas, ed. Kluwer Academic, Dordrecht, the Netherlands

Dubois, M., K. A. Gilles, J. K. Hamilton, P. A. Rebers, and F. Smith 1956. Colorimetric method for determination of sugars and related substances. Anal. Chem. 28:350-356.

Dunière, L., A. Gleizal, F. Chaucheyras-Durand, I. Chevallier, and D. Thévenot-Sergentet. 2011. Fate of Escherichia coli O26 in corn silage experimentally contaminated at ensiling, at silo opening, or after aerobic exposure, and protective effect of various bacterial inoculants. Appl. Environ. Microbiol. 77:8696-8704.

Filya, I. 2004. Nutritive value and aerobic stability of whole crop maize silage harvested at four stages of maturity. Anim. Feed Sci. Technol. 116:141-150.

Filya, I., and E. Sucu. 2010. The effects of lactic acid bacteria on the fermentation, aerobic stability and nutritive value of maize silage. Grass Forage Sci. 65:446-455.

Gollop, N., V. Zakin, and Z. G. Weinberg. 2005. Antibacterial activity of lactic acid bacteria included in inoculants for silage and in silages treated with these inoculants. J. Appl. Microbiol. 98:662-666.

Heinl, S., D. Wibberg, F. Eikmeyer, R. Szczepanowski, J. Blom, B. Linke, A. Goesmann, R. Grabherr, H. Schwab, A. Pühler, and A. Schlüter. 2012. Insights into the completely annotated genome of Lactobacillus buchneri CD034, a strain isolated from stable grass silage. J. Biotechnol. 161:153-166.

Hitchins, A. D., and K. Jinneman. 2011. BAM: Detection and enumeration of Listeria monocytogenes in foods. Bacteriol. Anal. Manual Chapter 10. Accessed Oct. 13, 2011. http://www.fda.gov/food/ foodscienceresearch/laboratorymethods/ucm071400.htm.

Hugas, M. 1998. Bacteriogenic lactic acid bacteria for the biopreservation of meat and meat products. Meat Sci. 49:139-150.

Kleinschmit, D. H., and L. Kung Jr. 2006. A meta-analysis of the effects of Lactobacillus buchneri on the fermentation and aerobic stability of corn and grass and small-grain silages. J. Dairy Sci. 89:4005-4013

Konosonoka, I. H., A. Jemeljanovs, B. Osmane, D. Ikauniece, and G. Gulbe. 2012. Incidence of Listeria spp. in dairy cows feed and raw milk in Latvia. ISRN Vet. Sci. 2012:435187.

Kristensen, N. B., A. Storm, B. M. L. Raun, B. A. Røjen, and D. L. Harmon. 2007. Metabolism of silage alcohols in lactating dairy cows. J. Dairy Sci. 90:1364-1377.

Krooneman, J., F. Faber, A. C. Alderkamp, O. S. J. H. W. Elferink, F. Driehuis, I. Cleenwerck, J. Swings, J. C. Gottschal, and M. Vancanneyt. 2002. Lactobacillus diolivorans sp. nov., a 1,2-propanediol-degrading bacterium isolated from aerobically stable maize silage. Int. J. Syst. Evol. Microbiol. 52:639-646.

Kung, L., Jr. 2009. Effects of microbial additives in silages: Facts and perspectives. Pages 7-22 in Proc. Int. Symp. Forage Qual. Conserv., vol. 1. M. Zopollatto, G. B. Muraro, and L. G. Nussio, ed. FEALQ, Piracicaba, Brazil.

Kung, L., Jr., M. R. Stokes, and C. J. Lin. 2003. Silage additives. Pages 305-360 in Silage Science and Technology. D. R. Buxton, R.
E. Muck, and J. H. Harrison, ed. American Society of Agronomy, CSSA, SSSA, Madison, WI.

Li, Y., and N. Nishino. 2011. Effects of inoculation of Lactobacillus rhamnosus and Lactobacillus buchneri on fermentation, aerobic stability and microbial communities in whole crop corn silage. J. Jpn. Grassl. Sci. 57:184-191.

Marciňáková, M., A. Lauková, M. Simonová, V. Strompfová, B. Koréneková, and P. Nad'. 2008. Probiotic properties of Enterococcus faecium EF9296 strain isolated from silage. Czech J. Anim. Sci. $53: 336-345$.

McDonald, P., A. R. Henderson, and S. J. E. Heron. 1991. The Biochemistry of Silage, 2nd ed. Chalcombe Publications, Lincoln, UK.

Ministério da Saúde. 2001. Regulamento Técnico Sobre os Padrões Microbiológicos para Alimentos. Pages 1-54 in Diário Oficial da República Federativa do Brasil. Resolução RDC n⿳0 12, de 02/01/2001. Agência Nacional de Vigilância Sanitária, Brasília, Brazil.

Moon, N. J. 1983. Inhibition of the growth of acid tolerant yeasts by acetate, lactate and propionate and their synergistic mixtures. J. Appl. Bacteriol. 55:454-460.

Muck, R. E. 2004. Effects of corn silage inoculants on aerobic stability. Trans. ASAE (Am. Soc. Agric. Eng.) 47:1011-1016.

Nishino, N. 2011. Aerobic stability and instability of silages caused by bacteria. Pages 127-141 in Proc. Int. Symp. Forage Qual. Conserv. J. L. P. Daniel, M. Zopollatto, L. G. Nussio, ed. Fundação de Estudos Agrários Luiz de Queiroz, Piracicaba, Brazil.

Nkosi, B. D., R. Meeske, D. Palic, T. Langa, K. J. Leeuw, and I. B. Groenewald. 2009. Effects of ensiling whole crop maize with bacterial inoculants on the fermentation, aerobic stability, and growth performance of lambs. Anim. Feed Sci. Technol. 154:193-203.

Nussio, L. G., F. P. Campos, and F. N. Dias. 2001. Importância da qualidade da porção vegetativa no valor alimentício da silagem de milho. Pages 127-145 in Simp. Sobre Prod. Util. Forragens Conserv. UEM Maringá, Brazil.

Oude Elferink, S. J., J. Krooneman, J. C. Gottschal, S. F. Spoelstra F. Faber, and F. Driehuis. 2001. Anaerobic conversion of lactic acid to acetic acid and 1,2-propanediol by Lactobacillus buchneri. Appl. Environ. Microbiol. 67:125-132.

Pell, A. N., and P. Schofield. 1993. Computerized monitoring of gas production to measure forage digestion in vitro. J. Dairy Sci. 76:1063-1073.

Rodrigues, P. H. M., J. M. Ruzante, A. L. Senatore, F. R. Lima, L. Melotti, and P. M. Meyer. 2004. Avaliação do uso de inoculantes microbianos sobre a qualidade fermentativa e nutricional da silagem de milho. R. Bras. Zootec. 33:538-545.

Rodriguez-Palacios, A., H. R. Staempfli, T. Duffield, and J. S. Weese. 2009. Isolation of bovine intestinal Lactobacillus plantarum and Pediococcus acidilactici with inhibitory activity against Escherichia coli $\mathrm{O} 157$ and F5. J. Appl. Microbiol. 106:393-401.

Rossi, F., and F. Dellaglio. 2007. Quality of silages from Italian farms as attested by number and identity of microbial indicators. J Appl. Microbiol. 103:1707-1715.

Saarisalo, E., E. Skytta, A. Haikara, T. Jalava, and S. Jaakkola. 2007. Screening and selection of lactic acid bacteria strains suitable for ensiling grass. J. Appl. Microbiol. 102:327-336.

Siqueira, G. R., T. F. Bernardes, and R. A. Reis. 2005. Instabilidade aeróbia de silagens: Efeitos e possibilidades de prevenção. Pages 25-60 in Volumosos na Produção de Ruminantes, 2 ed. R. A. Reis, G. R. Siqueira, and L. M. A. Bertipaglia, ed. Funep, Jaboticabal, Brazil.

Sohier, D., J. Coulon, and A. Lonvaud-Funel. 1999. Molecular identification of Lactobacillus hilgardii and genetic relatedness with Lactobacillus brevis. Int. J. Syst. Bacteriol. 49:1075-1081.

Tabacco, E., S. Piano, L. Cavallarin, T. F. Bernardes, and G. Borreani. 2009. Clostridia spore formation during aerobic deterioration of maize and sorghum silages as influenced by Lactobacillus buchneri and Lactobacillus plantarum inoculants. J. Appl. Microbiol. 107:1632-1641. 
Taylor, C. C., and L. Kung Jr. 2002. The effect of Lactobacillus buchneri 40788 on the fermentation and aerobic stability of high moisture corn in laboratory silos. J. Dairy Sci. 85:1526-1532.

te Giffel, M. C. T., A. Wagendorp, A. Herrewegh, and F. Driehuis. 2002. Bacterial spores in silage and raw milk. Antonie van Leeuwenhoek 81:625-630.
Vilar, M. J., E. Yus, M. L. Sanjuán, F. J. Diéguez, and J. L. Odríguezotero. 2007. Prevalence of and risk factors for Listeria species on dairy farms. J. Dairy Sci. 90:5083-5088.

Weese, J. S., and J. Rousseau. 2005. Evaluation of Lactobacillus pentosus WE7 for prevention of diarrhea in neonatal foals. J. Am. Vet. Med. Assoc. 226:2031-2034. 